\title{
自律送液が可能なマイクロチップと有機フォトダイオード検出器を用いる 化学発光分析システムの開発
}

\author{
曲 奎 智 ${ }^{1}$, 森岡 和大 ${ }^{2}$, 東 奈 穗 ${ }^{1}$, 長嶋 萌子 ${ }^{1}$, 辺見 彰秀 $^{3}$, 東海林 敦 $^{2}$, 村上 博哉 ${ }^{4}$,

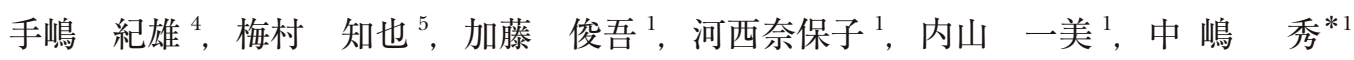

ポリジメチルシロキサン（PDMS）マイクロチップと有機フォトダイオード（OPD）検出器を用いる小型 で安価な化学発光分析システムを開発した．PDMS 樹脂は空気を溶解する性質があるので，本システムでは あらかじめ脱気したPDMS マイクロチップを用いることにより，送液ポンプを用いずにリザーバー内の試 料・試薬溶液をマイクロチャネルに自律的に送液することが可能である. Poly(3-hexylthiophene-2,5-diyl) と [6,6]-Phenyl-C61 butyric acid methyl ester 光電変換層とする OPD と脱気したPDMS マイクロチップを用い て化学発光分析システムを構築し，これを用いて過酸化水素の測定を検討したところ， $3.2 \mathrm{mM}$ 以下の濃度 に打いて良好な検量線が得られ, 検出限界は $4.4 \mu \mathrm{M}$ と見積もられた．また，本システムは市販の過酸化水素 分析キットと比較して, 試料と試薬の使用量を $1 / 5$ に削減できること, また, 分析時間を $1 / 10$ に短縮でき ることが明らかになった，さらに，本システムを用いて市販の殺菌消毒剂（オキシドール）中に含まれる過 酸化水素の定量を検討したところ, 本システムにより得られた過酸化水素の定量值はオキシドールの容器に 記載されている過酸化水素濃度と一致し, 本システムを用いて殺菌消毒剂中の過酸化水素を定量できること が確認された。

\section{1 緒言}

小型の分析機器を測定現場に持ち運び，試料を採取した その場で分析を実施することをオンサイト測定 ${ }^{122}$ という. オンサイト測定は，現場から持ち帰った試料を実験室で分 析する一般的な手法と比較して, 試料の変性や污染の防 止，分析結果の迅速な取得，試料輸送コストの削減など多 くの利点を有しており, 環境・医療・食品など幅広い分野 への応用が期待されている. 近年, 現場で, 誰もが, 簡便, 迅速かつ高感度に測定できる小型で安価な分析システムの 要望が高まってきて扮り, そのような要求を満たす新しい 分析システムの開発が国内外で精力的に進められている.

オンサイト測定に有用な分析技術の一つとして, マイク ロ化学分析システム ( $\mu \mathrm{TAS})$ がある ${ }^{3)}$ ）， $\mu \mathrm{TAS}$ では試料 量が数 $\mathrm{nL}$ 数十 $\mu \mathrm{L}$ と超微量であるため, 高感度な検出装

\footnotetext{
*E-mail : nakajima-hizuru@tmu.ac.jp

1 首都大学東京大学院都市環境科学研究科環境応用化学域 : 1920397 東京都八王子市南大沢 1-1

2 東京薬科大学薬学部 : 192-0392 東京都八王子市堀之内 1432-1

3 有限会社メビウスアドバンストテクノロジー: 167-0042 東京 都杉並区西荻北 3-31-6-105

${ }^{4}$ 愛知工業大学工学部応用化学科 : 470-0392 愛知県豊田市八草 町八千草 1247

5 東京薬科大学生命科学部：192-0392 東京都八王子市堀之内 1432-1
}

置と組み合わせて分析を行う必要がある。高感度な検出法 として, レーザー誘起蛍光法(6) 8), 熱レンズ検出法9) 11), 化学発光検出法 ${ }^{12)}{ }^{13}$ などが $\mu$ TAS の検出法として沉用され ているが, これらの検出法はレーザー, 顕微鏡, 光電子増 倍管などの大型かつ高価な周辺機器を使用するので, 分析 システム全体の大型化を招く，そのため, $\mu \mathrm{TAS}$ を用いて 現場で測定を実施することは極めて困難である.

この問題を解決するためのアプローチの一つとして, 有 機 EL（OLED）や有機フォトダイオード（OPD）などの有 機半導体素子を用いる蛍光/化学発光検出システム ${ }^{14)}$ １6) が注目されている. 有機半導体素子は, 真空蒸着法 ${ }^{17) ~} 19$,

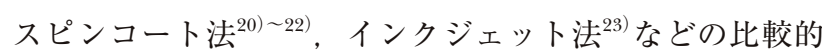
容易な方法により，平滑なガラス基板やプラスチック基板 上に自由な形状で作製できるため, 板状のマイクロチップ と相性がよい ${ }^{24)}$. また，有機材料の種類 ${ }^{25)}$ や配合比率 ${ }^{26)}$ 変えるなど成膜設計を工夫することにより，用途に合わせ た特性を持たせることが可能である，著者らはこれまで に, Tris(2-phenylpyridinato)iridium(III) [Ir(ppy $\left.)_{3}\right]$ と 4,4'-Di (N-carbazolyl) biphenyl（CBP）を発光層とする燐光 発光有機 ELを光源として用いるマイクロチップ用蛍光検 出システムを開発し， $\mu \mathrm{TAS}$ の検出系をダウンサイズ化す ることに成功している ${ }^{27) 28)}$. しかし, 試料溶液や試薬溶液 をマイクロチャネルに送液するためのポンプやバルブなど 
(a)

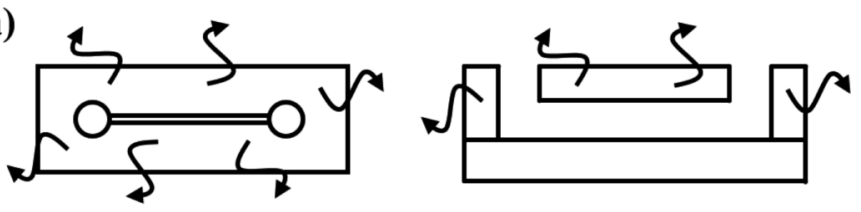

(b)
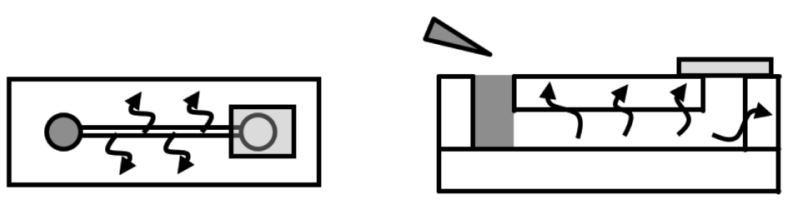

(c)
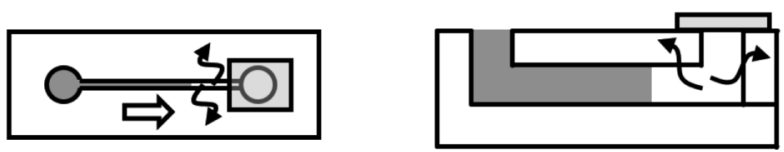

Fig. 1 Principle of the autonomous liquid transfer using a PDMS microfluidic device

の送液系のダウンサイズ化が課題として残されていた。

$\mu \mathrm{TAS}$ 用の送液システムには, 微少量の試料・試薬溶液 を低流量でも精度よく送液できるポンプが求められる。こ れまでに, 小型ポンプを用いる送液法 ${ }^{29)}$ や遠心力を利用し た送液法 ${ }^{30)}$ 32) などが報告されているが, これらの手法は 卓上サイズの専用装置と電源が必要であるという問題を抱 えている. 一方, ポリジメチルシロキサン (PDMS) マイ クロチップを用いて, ポンプなどの外部動力を必要とせず に液体をマイクロチャネルに送液する方法も報告されてい る ${ }^{33)}$ 34). この送液法の原理を Fig. 1 に示す. PDMS 樹脂は 空気を溶解する性質があり, 通常の室温・大気圧下では PDMS 樹脂には体積の $10 \%$ 程度の空気が溶け込んでい る.この空気の溶解度はヘンリーの法則に従い, PDMS 樹 脂が置かれた環境の気圧に比例して増減する。 そのため, 大気中にあった PDMS マイクロチップを真空下に移すと, Fig. 1（a）に示すように, PDMS 樹脂内部に溶解していた 空気が脱気される。このマイクロチップを大気圧下に戻 L, Fig. 1（b）に示すように, マイクロチップの片方のリ ザーバーを粘着テープなどで塞ぎ，もう一方のリザーバー に液体を入れると, マイクロチャネル内の空気が PDMS 樹 脂に再溶解するので, マイクロチャネル内が陰圧状態とな る. その結果, Fig. 1 (c) に示すように, リザーバー内の 液体がマイクロチャネルに自律的に送液される。この送液 法は，イムノアッセイ ${ }^{35)}, \mathrm{DNA}^{36)}$ 及びマイクロ $\mathrm{RNA}^{37)}$ の測 定などに応用されているが，測定に用いる検出システムが 大型かつ高価であるため, オンサイトで測定を実施するこ とは極めて困難であった.

そこで本研究では，オンサイト測定が可能な小型で安価 な $\mu \mathrm{TAS}$ を開発することを目的として, 自律送液が可能な PDMS マイクロチップと OPD 検出器を用いる新規化学発
光分析システムを開発した. 化学発光分析法は光源が不要 かつ高感度検出が可能であり, OPD を光検出器として用 いることにより，検出系の大幅なダウンサイズ化を実現で きる. 本研究では, 可視の幅広い波長領域において光応答 を示すことが報告されている Poly(3-hexylthiophene-2,5diyl) (P3HT) と [6,6]-Phenyl-C61 butyric acid methyl ester (PCBM）を光電変換層とする $\mathrm{OPD}^{38}$ をスピンコート法に より作製し，作製した OPDの分光感度特性を評価した。ま た，PDMS マイクロチップを用いた自律送液法について は, マイクロチップの脱気時間と流速の関係を検討した. さらに，開発した化学発光分析システムを用いて，市販の 殺菌消毒剤（オキシドール）中に含まれる過酸化水素の定 量を検討した。

$$
2 \text { 実験 }
$$

\section{$2 \cdot 1$ 試 薬}

本研究では, 特に断りのない限り特級グレードの試薬を 使用した。 また，水はすべて日本ミリポア製 Direct-Q シス テムにより精製した超純水を使用した. PDMS プレポリ マーと硬化剤は, 東レ・ダウコーニング製の SILPOT 184 を 用いた. Poly(3,4-ethylenedioxythiophene)doped with poly (4-styrenesulfonate)（PEDOT/PSS）は, シグマアルドリッ チ製のものを使用した. P3HT と PCBM は東京化成工業製 のものを用いた. OPDの封止剤は Ossila 製の Encapsulation Epoxyを使用した. Cica Clean LX- II, アセトン，2-プロ パノール, ヨウ化水素酸, エタノール, リン酸二水素ナト リウム, リン酸水素二ナトリウム, 塩化ナトリウム及び過 酸化水素は関東化学から購入したものを使用した．西洋わ さびペルオキシダーゼ（HRP）は富士フイルム和光純薬製 のものを使用した. 化学発光基質は Thermo Fisher Scientific 

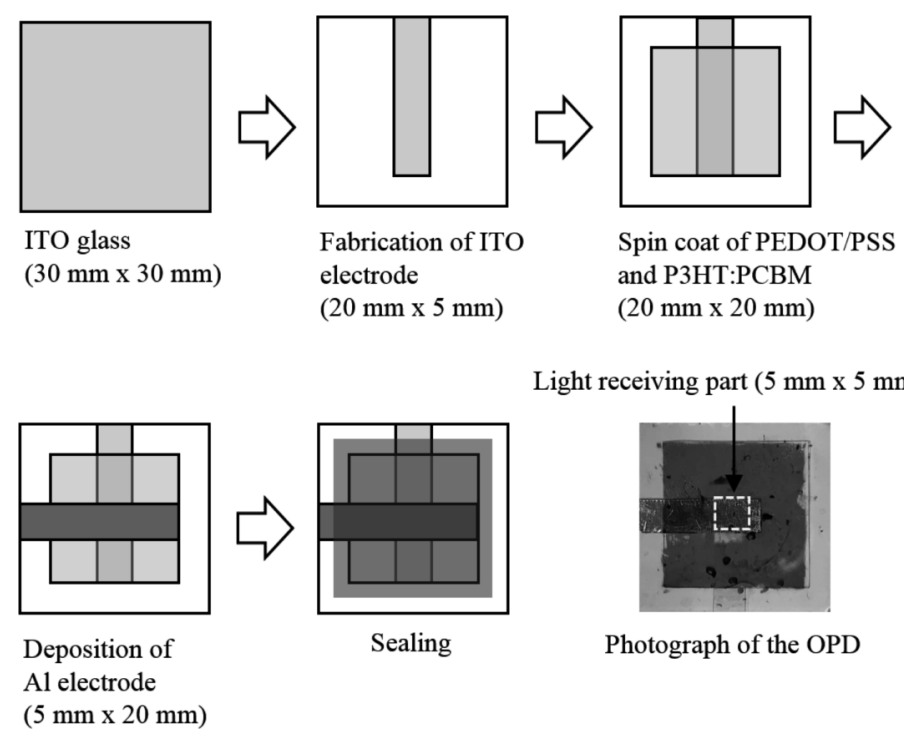

Light receiving part $(5 \mathrm{~mm} \times 5 \mathrm{~mm})$

Fig. 2 Scheme for fabricating the OPD

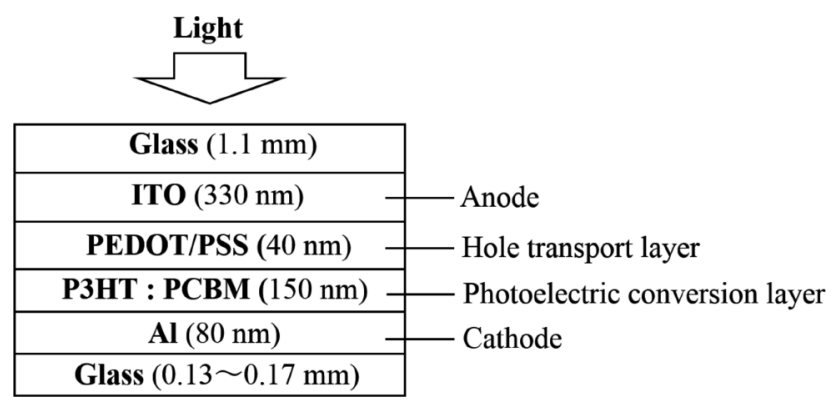

Fig. 3 Structure of the OPD

製のSuper Signal ${ }^{\mathrm{TM}}$ ELISA Femto substrate を使用した.オ キシドールは健栄製薬製のものを使用した.

\section{$2 \cdot 2$ OPD の作製}

Fig. 2 に本研究で使用した OPD の作製手順を示す。ま ず, 酸化インジウムスズ（ITO）が $330 \mathrm{~nm}$ 成膜されたガ ラス基板 $(100 \mathrm{~mm} \times 100 \mathrm{~mm} \times 1.1 \mathrm{~mm}$ ，ジオマテック製） を, 薄層プレートカッター (2010, 大成化光製) を用いて $30 \mathrm{~mm} \times 30 \mathrm{~mm}$ のサイズにカットした. このガラス基板の ITO が成膜されている面に, カッティングマシーン（Craft ROBO CC200-20，GRAPHTEC 製）を用いて $5 \mathrm{~mm} \times 20$ $\mathrm{mm}$ のサイズにカットした厚さ $85 \mu \mathrm{m}$ のアクリル/シリ コーン系両面粘着シート（4377N-85，3M 製）を貼り付け た.この基板をヨウ化水素酸に 30 分間浸漬し, 両面粘着 シートが貼られていない部分の ITOを溶解した. 基板を水 で十分にすすいだのち, 両面粘着シートを剥がし, エ夕 ノールで洗浄することにより, ガラス基板上に ITO 電極を 作製した. この ITO 電極基板を, 超音波洗浄器 (5210, ブ ランソン製）を用いて, $10 \mathrm{v} / \mathrm{v} \%$ Cica Clean LX- II 水溶液, 水, アセトン, 2-プロパノールの順に 10 分間ずつ洗浄し
た. 次に, この電極基板上に, 2-プロパノールを用いて調 製した $10 \mathrm{v} / \mathrm{v} \%$ PEDOT/PSS 溶液を，スピンコーター （K-359S-1，共和理研製）を用いて，1900 rpm で 60 秒間ス ピンコートした.この基板をホットプレート（NINOS NA-2, ASONE 製) を用いて $120{ }^{\circ} \mathrm{C}$ で 5 分間ベークするこ とにより, ITO 電極基板上に PEDOT/PSS 薄膜を形成し た。次に, P3HT : PCBM 溶液を, $1000 \mathrm{rpm}$ で 5 秒間, さ らに $2500 \mathrm{rpm}$ で 55 秒間スピンコートし, $55{ }^{\circ} \mathrm{C}$ で 25 分間 ベークすることにより，基板上に P3HT : PCBM 薄膜を形 成した。この基板上の余分な PEDOT/PSS 層と P3HT : PCBM 層をアセトンを用いて除去し，基板中央部に 20 $\mathrm{mm} \times 20 \mathrm{~mm}$ の有機層を形成した．次に，この基板を真空 蒸着装置（E-120 型，ALS テクノロジー製）に搬入し，ア ルミニウム電極を作製した. さらに，この基板を真空蒸着 装置に接続されたグローブボックス（KK-011AS， KOREA KIYON 製) に移動させ, カバーガラス (C022221, MATSUNAMI 製）を $20 \mathrm{~mm} \times 20 \mathrm{~mm}$ のサイズにカットして作製した封 止用ガラスとこの基板を, 封止剤を用いて接着することに より，OPDを作製した．この OPD は Fig. 3 に示すような 構造となっており, 基板中央部に $5 \mathrm{~mm} \times 5 \mathrm{~mm}$ の受光部 が存在する。

\section{2·3 PDMS マイクロチップの作製}

Fig. 4 に本研究で使用した PDMS マイクロチップの構造 を示す.まず, PDMS プレポリマーと硬化剤を重量比 $10: 1$ の割合で混合した溶液を真空ポンプ（G-25SA，到達圧力 $9.3 \mathrm{~Pa}$, ULVAC 製）と吸引鐘（VT-500，ADVANTEC 製） を用いて脱気し，これを幅 $10 \mathrm{~mm} \times$ 長さ $40 \mathrm{~mm} \times$ 深さ $2 \mathrm{~mm}$ のアクリル製の型に注ぎ, $70{ }^{\circ} \mathrm{C}$ のオーブン（ST110, ESPEC 製) 内に 3 時間静置することにより PDMS を 


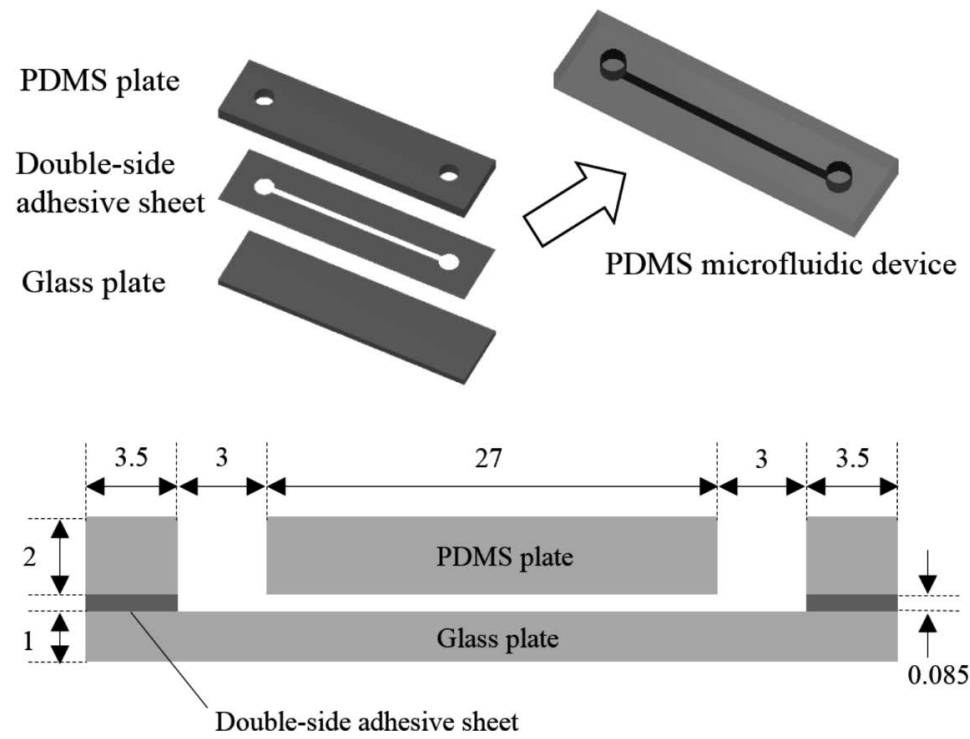

Fig. 4 Structure of the PDMS microfluidic device

The unit of the numerical values in this figure is $\mathrm{mm}$.

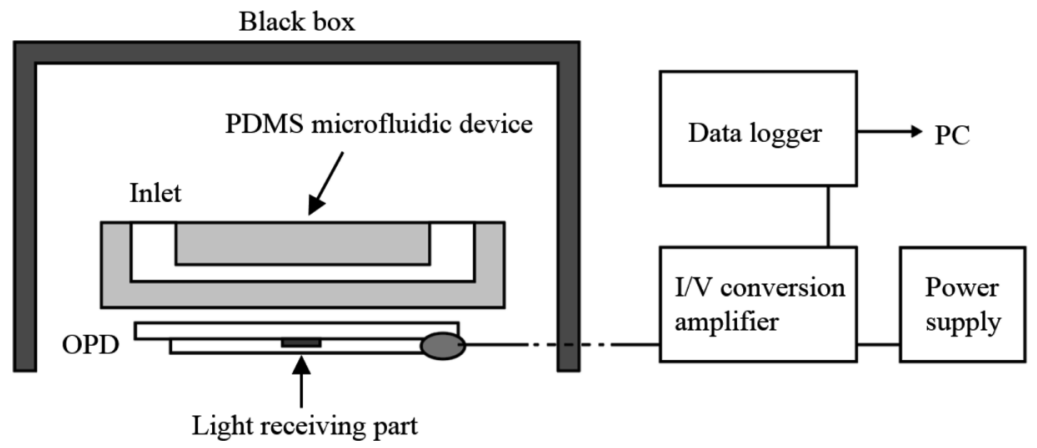

Fig. 5 Configuration of the chemiluminescence analysis system

硬化させた。この PDMS 樹脂を型から剥離し, 生検卜レパ ン（BPP-30F，カイインダストリーズ製）を用いてリザー バーとなる直径 $3 \mathrm{~mm}$ の貫通孔を形成することにより，幅 $10 \mathrm{~mm} \times$ 長さ $40 \mathrm{~mm} \times$ 厚さ $2 \mathrm{~mm}$ の平板状の PDMS 基板 を作製した．次に，厚さ $1 \mathrm{~mm}$ のスライドガラス（S1111， MATSUNAMI 製) を薄層プレートカッター（2010, 大成化 光製）を用いて幅 $10 \mathrm{~mm} \times$ 長さ $40 \mathrm{~mm}$ のサイズにカット した。 また，カッティングマシーン（Craft ROBO CC20020, GRAPHTEC 製）を用いて, 厚さ $85 \mu \mathrm{m}$ のアクリル/ シリコーン系両面粘着シート（4377N-85，3M 製）に幅 $1 \mathrm{~mm} \times$ 長さ $33 \mathrm{~mm}$ の流路となるスリットを作製し，この シートを幅 $10 \mathrm{~mm} \times$ 長さ $40 \mathrm{~mm}$ のサイズにカットした。 このようにして作製したアクリル/シリコーン系両面粘着 シートをPDMS 基板とガラス基板の間に挟み, これらを貼 り合わせることにより, 幅 $1 \mathrm{~mm} \times$ 長さ $27 \mathrm{~mm} \times$ 深さ 85 $\mu \mathrm{m}$ の直線形状のマクロチャネルを有する幅 $10 \mathrm{~mm} \times$ 長さ
$40 \mathrm{~mm} \times$ 厚さ $3.1 \mathrm{~mm}$ の PDMS マイクロチップを作製した.

\section{$2 \cdot 4$ 化学発光分析システムの構築}

Fig. 5 に本研究で開発した化学発光分析システムの構成 を示す。このシステムは，スコッチテープ（3M 製）を用 いてマイクロチャネルの中央部分に OPDを貼り付けた PDMS マイクロチップ, 電流/電圧（I/V) 変換アンプ（メ ビウスアドバンストテクノロジー製)，データロガー （ADC-24，Pico Technology 製）及び直流定電圧電源（DK910，サンハヤト製）から構成されている. PDMS マイクロ チップのマイクロチャネル内で化学反応により生じた発光 は, OPD で光電流に変換され, I/V 変換アンプにより電圧 に変換されたのち，データロガーによりデジタル信号に変 換されて PCに記録される．測定条件の設定と測定デー夕 の記録は，データロガーに付属する専用のソフトウエア （PicoLog Ver. 5.25.3）を用いて行った. すべての測定は暗 


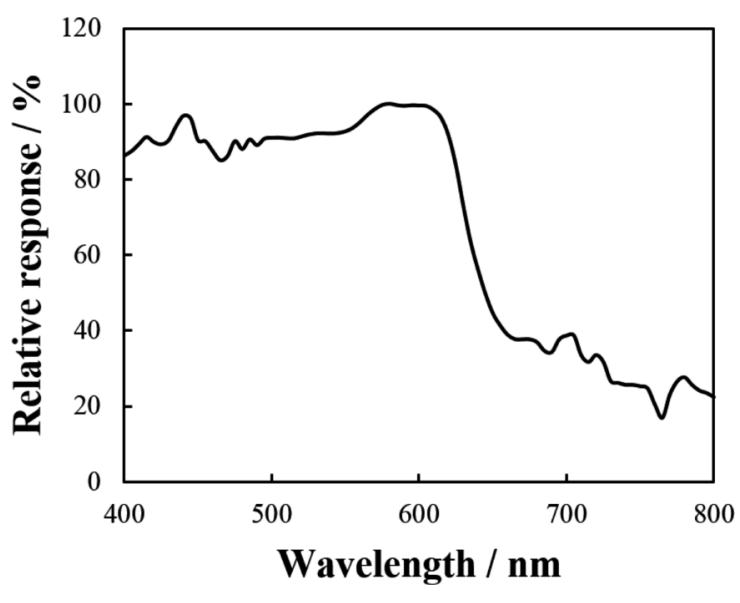

Fig. 6 Spectral sensitivity characteristic of the OPD

箱内で実施し，測定データのサンプリングインターバルは 0.5 秒または 7.5 秒（積算平均）とした.

\section{3 結果と考察}

\section{$3 \cdot 1$ OPD の特性評価}

蛍光分光高度計（RF-5300PC, 島津製）のモノクロメー ターからの $400 \mathrm{~nm}$ から $800 \mathrm{~nm}$ の波長領域における単色 光を, $5 \mathrm{~nm}$ 間隔で OPD に照射したときの OPD の応答を 測定することにより, OPD の分光感度特性を評価した。こ のとき, モノクロメーターから照射される単色光の強度は 波長によって異なるので, 校正済みのフォトダイオードセ ンサー（PD300, Ophir Optronics 製）とパワーメーター (Vega, Ophir Optronics 製) を用いてモノクロメーターか ら照射された単色光の強度を測定し, 式(1) を用いて OPD の分光感度を算出した。

$$
\text { Relative response }(\%)=\frac{I_{O}}{I_{P} \cdot I_{M a x}} \times 100
$$

ここで, $I_{O}$ は OPD で測定した単色光の強度, $I_{P}$ はパワー メーターで測定した単色光の強度, $I_{M a x}$ は $\frac{I_{O}}{I_{P}}$ の最大值を 示す. Fig. 6 に本研究で作製した OPD の分光感度特性を示 す.この図から，作製した OPD は $400 \mathrm{~nm} \sim 620 \mathrm{~nm}$ の幅 広い波長領域の光に対して応答することがわかった。この OPD の分光感度特性は, 既報の P3HT : PCBM を光電変換 層に用いるOPDの特性に類似していた ${ }^{21) 38)}$. 本研究におい て化学発光基質として使用する Super Signal ${ }^{\mathrm{TM}}$ ELISA Femto substrate は, 過酸化水素と HRP の存在下で $425 \mathrm{~nm}$ に極大発光を示す化学発光を生じるため, 作製した OPD はこの化学発光を検出できると推測される.

次に，作製した OPDの光応答の安定性と再現性を評価

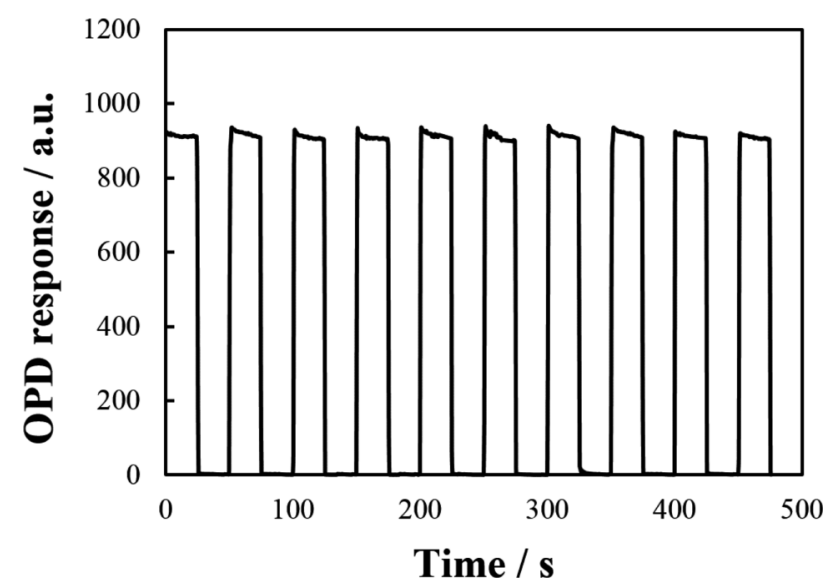

Fig. 7 Response of the OPD to the blue LED light Sampling interval, $0.5 \mathrm{~s}$.

するために，青色 LED（OSUB5161A-PQ，極大発光波長 $470 \mathrm{~nm}$, OptoSupply 製) の光を OPD 25 秒間隔で照射/ 遮光する操作を 10 回繰り返し, そのときの OPD の応答を 測定した. Fig. 7 に青色 LED 光に対する OPD の応答を示 す.作製した OPD にLED 光を照射すると, OPD は瞬時に 最大の応答を示した，その後，応答はわずかに減少し，10 秒以降ではほぼ一定となった。 そこで, 光を照射してから 10 秒から 25 秒における OPDの応答の相対標準偏差 （RSD）を算出したところ, RSDは $0.12 \%$ と見積もられた. このことから，OPD に光が照射されてから 10 秒後に測定 を開始すれば, 精度よく測定できることがわかった。また, 10 回の繰り返し測定における OPD の応答の RSD は $0.89 \%$ と見積もられた。このことは，作製した OPD が再現性よ く光に応答することを示しており，この OPD を化学発光 分析の光検出器として十分に使用できる可能性があること が示唆された.

\section{$3 \cdot 2$ PDMS マイクロチップを用いた自律送液}

脱気したPDMS マイクロチップを用いて液体を自律的に マイクロチャネルに送液するときの流速は, マイクロチッ プのサイズや脱気時間に依存すると推測される. そこで, PDMS マイクロチップを用いて試料溶液を再現性よく送液 するために, 脱気時間の最適化を検討した. $2 \cdot 3$ で作製し た PDMS マイクロチップを, 真空ポンプ (G-25SA, 到達圧 力 $9.3 \mathrm{~Pa}$, ULVAC 製) と吸引鐘（VT-500, ADVANTEC 製) を用いて， 0，5，10，20，30，60，90 及び 120 分間脱気し たのち, 片方のリザーバーをプレートシール（547-SBS-PP, 深 江化成製) で塞ぎ，もう一方のリザーバーに水を $20 \mu \mathrm{L}$ 入 れた.これにより,リザーバー内の水がマイクロチャネル に自律的に送液される様子を観察した。 このときの水の流 速は, マイクロチャネル内を流れる水の先端が一定距離を 移動するのに要する時間を測定することにより算出した. 


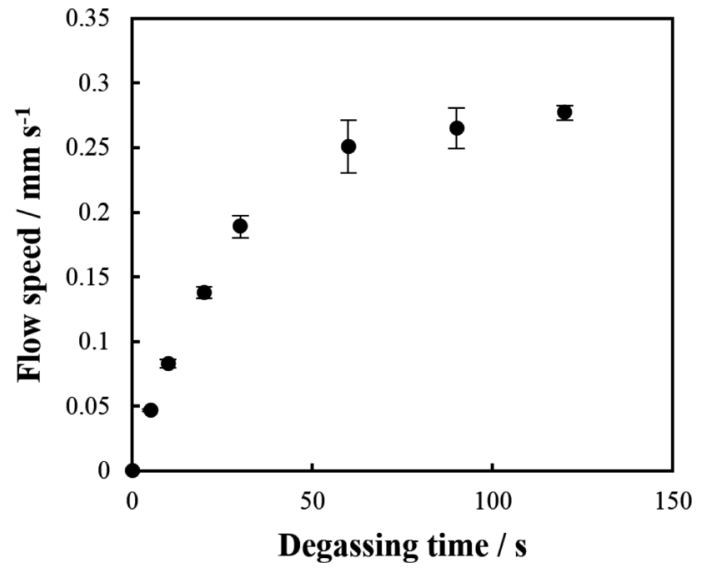

Fig. 8 Relationship between the degassing time of the PDMS microfluidic device and the flow speed of the water flowing in the microchannel

Fig. 8 にPDMS マイクロチップの脱気時間とマイクロ チャネル内を流れる水の流速の関係を示す．脱気していな いPDMS マイクロチップのリザーバーに水を入れた場合, PDMS 樹脂は疎水性なのでリザーバー内の水はマイクロ チャネルに流れなかった，一方，脱気したPDMS マイクロ チップのリザーバーに水を入れた場合，マイクロチャネル 内の空気が PDMS 樹脂に溶解し, マイクロチャネル内が陰 圧状態となるので, リザーバー内の水がマイクロチャネル に吸引・送液された。このときの流速は, 脱気時間が長く なるにしたがって増加し，60 分間脱気したときの流速は $0.25 \mathrm{~mm} \mathrm{~s}^{-1}$ であった。 また，各脱気時間における流速の RSD $(n=5)$ は $1.7 \sim 8.1 \%$ と見積もられ，脱気したPDMS マイクロチップを用いてリザーバー内の試料・試薬溶液を 再現性よくマイクロチャネルに送液できることが確認され た。な押，PDMS マイクロチップの脱気時間は，最も流速 が速く, RSD 值も小さい 120 分が最適であるが，以後の実 験では，流速と脱気時間のバランスを考慮して，60 分間脱 気したPDMSマイクロチップを用いて実験を行うことにし た.

\section{$3 \cdot 3$ 過酸化水素の測定}

開発した化学発光分析システムを用いて過酸化水素の測 定を検討した．OPDを貼り付けたPDMS マイクロチップ を真空ポンプと吸引鐘を用いて 1 時間脱気したのち, PDMS マイクロチップの片方のリザーバーをプレートシー ルで塞いだ. 次に，もう一方のリザーバーに $20 \mu \mathrm{L}$ の 0.66 $\mathrm{mg} \mathrm{mL}^{-1} \mathrm{HRP}$ 水溶液を入れ, 自律送液によりマイクロチャ ネルに HRP 水溶液を導入した。この状態でマイクロチッ プを 30 分間静置することにより，マイクロチャネルの内 壁にHRPを固定化した，次に，リザーバーに貼ったプレー トシールを剥がし， $0.14 \mathrm{M} \mathrm{NaCl}$ を含む $0.1 \mathrm{M}$ リン酸緩衝

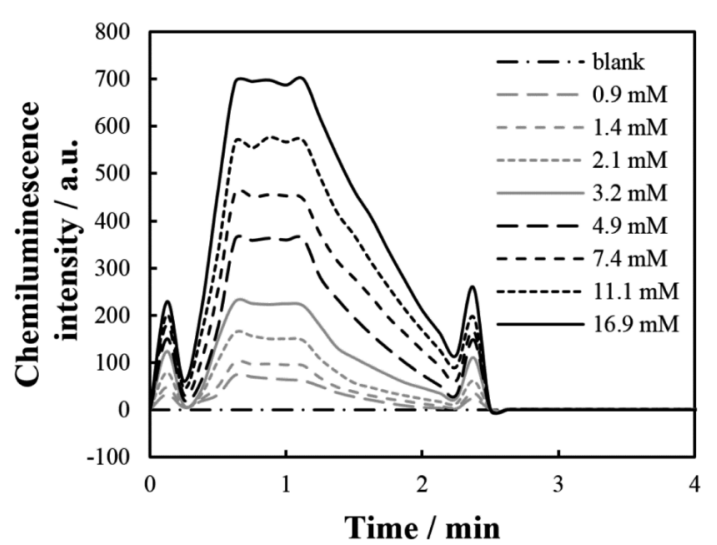

Fig. 9 OPD response for sample solutions containing various concentrations of hydrogen peroxide

Sampling interval, $7.5 \mathrm{~s}$.

液（pH 7.4）を用いてマイクロチャネル内を洗浄した。こ の PDMS マイクロチップを再び 1 時間脱気したのち, 片方 のリザーバーをプレートシールで塞ぎ，もう一方のリザー バーに化学発光基質と $0 \sim 16.6 \mathrm{mM}$ 過酸化水素を含む試料 溶液 $20 \mu \mathrm{L}$ を入れ, 自律送液により試料溶液をマイクロ チャネルに導入した。 このとき, マイクロチャネルの内壁 に固定化されている HRP が触媒となり, 試料溶液中に含 まれている過酸化水素と化学発光基質が反応し, 化学発光 を生じる。この発光強度をマイクロチップに貼り付けた OPD で測定することにより, 試料溶液中に含まれる過酸 化水素を定量した.

Fig. 9 に種々の濃度の過酸化水素を含む試料溶液に対す る OPD の応答を示す。なお, この図では過酸化水素と化 学発光基質を含む試料溶液をリザーバーに入れたときを 0 分としている．過酸化水素と化学発光基質を含む試料溶 液をリザーバーに入れると, 化学発光強度は徐々に増加 し, 約 40 秒後に最大となった. その後, 1 分 10 秒から発 光強度は徐々に減少し, 2 分 30 秒以降は一定となった。試 料溶液の流速を $0.25 \mathrm{~mm} \mathrm{~s}^{-1}$ とし, 化学発光強度が最大と なる領域の時間から見積もった OPD の受光部の位置は, 実際にマイクロチップに固定した OPD の受光部の位置と 一致していた。また，この測定では試料ピークの両端にも 小さなピークが観測された. HRP はマイクロチャネルの内 壁だけでなくリザーバーの内壁にも固定化されているの でリザーバーに試料溶液を入れたときと、、イクロチヤ ネルを流れる試料溶液が反対側のリザーバーに到達したと きにもリザーバー内で化学発光が生じる，したがって，試 料ピーク両端の小さなピークは, リザーバー内での発光の 散乱光がマイクロチャネル中央部に設置された OPD の受 光部に入射し, ピークとして観測されたものと推測され る. OPD とマイクロチップの間にスリットを有する遮光 
板を設置して, OPDへの散乱光の入射を防止すれば，この ようなピークは現れなくなると考えられる.

Fig. 10 に発光強度が最大となった 40 秒から 1 分 10 秒の 間の化学発光強度の平均值を過酸化水素の濃度に対してプ ロットすることにより作成した過酸化水素に対する検量線 を示す。過酸化水素の濃度が増加するにしたがって化学発 光強度は増大し, $3.2 \mathrm{mM}$ 以下の濃度範囲において作成し た検量線は相関係数 $\mathrm{R}^{2}=0.9986$ の良好な直線性を示した. このとき, 5 回の繰返し測定における RSD は $1.3 〜 18 \%$ と 見積もられ，ブランクの標準偏差の 3 倍から算出した過酸 化水素の検出限界は $4.4 \mu \mathrm{M}$ であった. これらの結果は, 本 研究で開発した化学発光分析システムを用いて過酸化水素 を定量できることを示している.

\section{$3 \cdot 4$ 殺菌消毒剤中に含まれる過酸化水素の定量}

開発した化学発光分析システムを用いて, 市販の殺菌消 毒剂 (オキシドール) 中に含まれる過酸化水素の定量を検 討した.オキシドールを水で 500 倍希釈した溶液を試料溶 液として用い, 前項と同様の方法で測定したところ, オキ シドール中に含まれる過酸化水素の濃度は, $2.97 \pm 0.07$ $\mathrm{w} / \mathrm{v} \% （ n=8 ）$ と見積もられた. オキシドールの容器に記 載されている過酸化水素の濃度は $2.5 \sim 3.5 \mathrm{w} / \mathrm{v} \%$ であり, 本システムにより得られた定量值は記載濃度と一致してい

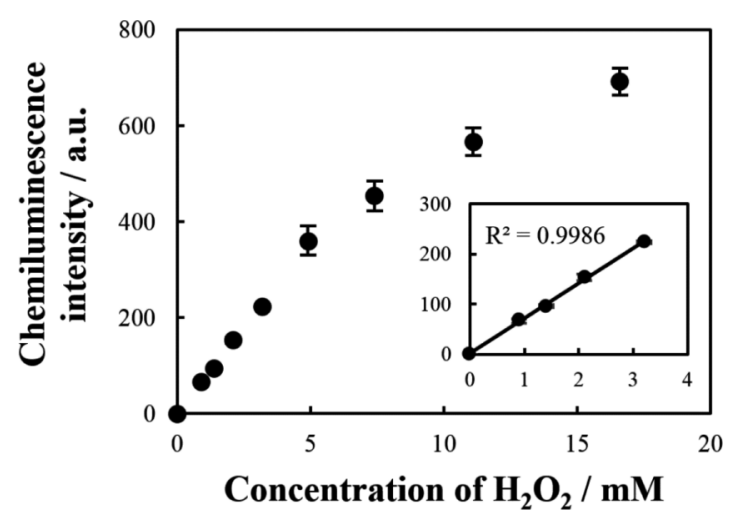

Fig. 10 Calibration curve for hydrogen peroxide
た.この結果から，本研究で開発したシステムを，過酸化 水素を含む薬品の品質管理に応用できる可能性があること が示唆された.

\section{$3 \cdot 5$ 市販の過酸化水素分析キットとの比較}

Table 1 に市販の過酸化水素分析キットと本研究で開発 した化学発光分析システムを用いる過酸化水素測定法の比 較を示す. 市販の 96 穴マイクロプレートを用いる過酸化 水素分析キット ${ }^{39)}$ では 30 分のインキュベーション時間が 必要であるが, 本法ではマイクロチャネル内で化学反応と 検出を同時に行うので，過酸化水素を 3 分ほどで測定可能 であり，分析時間を $1 / 10$ に短縮することができた．また， 測定に使用する試料と試薬の量も $100 \mu \mathrm{L}$ から $20 \mu \mathrm{L}$ へ $1 / 5$ に削減することができた.

市販の 96 穴マイクロプレートを用いる過酸化水素分析 キットでは, 検出に大型で高価なプレートリーダーが必要 であるが，本法で使用するマイクロチップと OPD は手の ひらサイズであり, 大量生産すれば低コスト化も可能であ る. 現時点では, 本システムは市販の電源とデータロガー を使用しているので持ち運びには適さないが, 著者らが以 前に開発した携帯型 ELISA システム ${ }^{40)}$ の電源やデータロ ガーを活用すれば, 本システムをバッテリー駆動が可能な 周辺機器も含めて手のひらサイズの化学発光分析システム へと改良することも容易に可能である.オンサイト測定で 問題となるマイクロチャネル内壁への酵素の固定化とマイ クロチップの脱気については, あらかじめ酵素の固定化と 脱気処理を施したマイクロチップを真空パックの中に保存 して測定現場に持参すれば，現場で前処理をせずにそのま ま測定することも可能である。したがって，本システムは 河川等のフィールドにおける環境計測, ベッドサイドや在 宅での医療検査, 食品販売店での品質管理などに極めて有 用な分析システムとなると考えられる.

\section{4 結 言}

本研究では, 小型で安価なオンサイト測定用化学発光分 析システムを開発することを目的として, 脱気したPDMS

Table 1 Comparison of analytical methods for measuring hydrogen peroxide

\begin{tabular}{lll}
\hline & Hydrogen peroxide assay kit & \multicolumn{1}{c}{ Developed system } \\
\hline Substrate & Amplex ${ }^{\circledR}$ Red & Super Signal ${ }^{\text {TM }}$ ELISA Femto substrate \\
Enzyme & HRP & HRP \\
Reaction field & 96 -well microplate & PDMS microfluidic device \\
Detection method & Fluorescence or absorbance & Chemiluminescence \\
Detector & Microplate reader & Organic photodiode \\
Volume of sample and reagent solution & $100 \mu \mathrm{L}$ & $20 \mu \mathrm{L}$ \\
Incubation time & $30 \mathrm{~min}$ & $3 \mathrm{~min}$ \\
\hline
\end{tabular}


マイクロチップと OPD 検出器を組み合わせた新規化学発 光分析システムを開発した。 スピンコート法により作製し た OPD は $400 \mathrm{~nm} \sim 620 \mathrm{~nm}$ の波長領域の光に対して優れ た応答を示し, 化学発光分析用の小型光検出器として十分 に機能した。また，PDMS マイクロチップを用いた自律送 液については，チップの脱気時間を最適化することによ り, 安定した送液を実現した。開発した化学発光分析シス テムを用いる過酸化水素の測定では, 従来法と比較して, 装置の小型化，試料・試薬量の削減，分析時間の短縮に成 功した. 本研究で開発した化学発光分析システムは, PDMS マイクロチップのマイクロチャネル内壁に固定化す るタンパク質の種類を変えることにより，過酸化水素の測 定だけでなく，酵素免疫測定法による抗体の測定などにも 応用できる可能性がある。したがって，データロガーや電 源などの周辺機器を小型化し，システム全体を持ち運びで きるようにダウンサイズ化すれば，本システムは河川等の フィールドにおける環境計測, ベッドサイドや在宅での医 療検査, 食品販売店での品質管理などに極めて有用な分析 システムとなると考えられる。

\section{謝辞}

本研究の一部は, 日本学術振興会科学研究費補助金 (15K05544，17K14504，18H02009，19K05227及び 19H02751）と東京都の支援によりなされたことを付記し, ここに謝意を表します。

$$
\left(\begin{array}{c}
2019 \text { 年 } 10 \text { 月 } 11 \text { 日, 第 } 56 \text { 回フローインジェ } \\
\text { クション分析講演会において, 一部発表 }
\end{array}\right)
$$

\section{文献}

1) 樋口慶郎，井上亜希子，玉之内啓満，服部隆康，本 水 昌二：分析化学 (Bunseki Kagaku), 48,477 (1999).

2) 村田光明，池田貴昭，三枝正彦，石田 誠，澤田和 明: 分析化学 (Bunseki Kagaku), 60, 499 (2011).

3) Castillo-León, Jaime, Svendsen, Winnie E. (Eds.) : "Lab-on-a-Chip Devices and Micro-Total Analysis Systems", (2015), (Springer International Publishing, Switzerland).

4) M. Kovarik, D. Ornoff, A. Melvin, N. Dobes, Y. Wang, A. Dickinson, P. Gach, P. Shah, N. Allbritton: Anal. Chem., 85, 451 (2013).

5) D. Patabadige, S. Jia, J. Sibbitts, J. Sadeghi, K. Sellens, C. Culbertson : Anal. Chem., 88, 320 (2016).

6) S. Lai, S. Wang, J. Luo, L. Lee, S. Yang, M. Madou : Anal. Chem., 76, 1832 (2004).

7) N. Yanagisawa, D. Dutta: Anal. Chem., 84, 7029 (2012).

8) M. Seia, S. Pereira, C. Fontán, I. Vito, G. Messina, J. Raba : Sens. Actuators B, 168, 297 (2012).

9) K. Sato, M. Yamanaka, T. Hagino, M. Tokeshi, H. Kimura, T. Kitamori : Lab Chip, 4, 570 (2004).

10) E. Dong, Y. Xu, Z. Liu, Y. Fu, T. Ohashi, Y. Tanaka, K. Mawatari, T. Kitamori : Lab Chip, 11, 2153
(2011).

11) T. Kitamori, M. Tokeshi, A. Hibara, K. Sato : Anal. Chem., 76, 52A (2004)

12) K. Tsukagoshi, N. Jinno, R. Nakajima : Anal. Chem. 77, 1684 (2005).

13) Y. Guan, Z. Xu, J. Dai, Z. Fang : Talanta, 68, 1384 (2006).

14) E. Manna, T. Xiao, J. Shinar, R. Shinar : Electronics, 4, 688 (2015).

15) N. Pires, T. Dong, U. Hanke, N. Hoivik: Sensors, 14, 15458 (2014).

16) G. Williams, C. Backhouse, H. Aziz: Electronics, 3 43 (2014)

17) M. Sagmeister, A. Tschepp, E. Kraker, T. Abel, B. Lamprecht, T. Mayr, S. Köstler : Anal. Bioanal. Chem., 405, 5975 (2013)

18) B. Lamprecht, A. Tschepp, M. Čajlaković, M. Sagmeister, V. Ribitsch, S. Köstler : Analyst, 138 5875 (2013)

19) R. Liu, R. Ishimatsu, M. Yahiro, C. Adachi, K Nakano, T. Imato : Talanta, 132, 96 (2015).

20) T. Dong, N. Pires : Biosens. Bioelectron., 94, 321 (2017).

21) F. Lefèvre, P. Juneau, R. Izquierdo : Sens. Actuators $B, 221,1314$ (2015).

22) N. Pires, T. Dong: Sensors, 13, 15898 (2013).

23) L. Lavery, G. Whiting, A. Arias : Org. Electron., 12 $682(2011)$.

24) C. Merfort, K. Seibel, K. Watty, M. Böhm : Microelectron. Eng., 87, 712 (2010).

25) X. Xi, W. Li, J. Wu, J. Ji, Z. Shi, G. Li : Sol. Energy Mater. Sol. Cells, 94, 2435 (2010).

26) T. Luong, Z. Chen, H. Zhu : Sol. Energy Mater. Sol. Cells, 94, 1059 (2010).

27) H. Uoyama, K. Goushi, K. Shizu, C. Adachi : Nature, 492, 234 (2012).

28) H. Nakajima, Y. Okuma, K. Morioka, M. Miyake, A Hemmi, T. Tobita, M. Yahiro, D. Yokoyama, C. Adachi, N. Soh, K. Nakano, S. Xue, H. Zeng, K Uchiyama, T. Imato : J. Sep. Sci., 34, 2906 (2011).

29) X. Wang, H. Jiang, Y. Chen, X. Qiao, L. Dong : Sens. Actuators A, 253, 27 (2017).

30) 森岡和大, 中嶋 秀, 辺見彰秀, 曽 湖烈, 内山一 美：分析化学 (Bunseki Kagaku), 62, 65 (2013).

31) A. Hemmi, T. Usui, A. Moto, T. Tobita, N. Soh, K. Nakano, H. Zeng, K. Uchiyama, T. Imato, H. Nakajima : J. Sep. Sci., 34, 2913 (2011).

32) M. Czugala, D. Maher, F. Collins, R. Burger, F. Hopfgartner, Y. Yang, J. Zhaou, J. Ducrée, A. Smeaton, K. Fraser, F. Benito-Lopez, D. Diamond : RSC Adv., 3, 15928 (2013).

33) H. Okada, K. Hosokawa, M. Maeda : Anal. Sci., 27, 237 (2011).

34) 石原 量, 長谷川和貴, 細川和生：分析化学 (Bunseki Kagaku), 64, 319 (2015).

35) K. Hosokawa, M. Omata, K. Sato, M. Maeda : Lab Chip, 6, 236 (2006).

36) K. Hosokawa, K. Sato, N. Ichikawa, M. Maeda : Lab Chip, 4, 181 (2004).

37) H. Arata, H. Komatsu, A. Han, K. Hosokawa, M. Maeda : Analyst, 137, 3234 (2012).

38) X. Wang, M. Amatatongchai, D. Nacapricha, O. Hofmann, J. Mello, D. Bradley, A. Mello : Sens Actuators B, 140, 643 (2009). 
39) Amplex ${ }^{\circledR}$ Red Hydrogen Peroxide/Peroxidase Assay Kit, Catalog No. A22188, Thermo Fisher Scientific.

40) H. Singh, K. Morioka, M. Shimojima, L. An, H.
Nakajima, A. Hemmi, K. Uchiyama, S. Loong, S. AbuBakar, M. Yang, M. Sugamata : Jpn. J. Infect. Dis., 69, 435 (2016).

\title{
Development of a Chemiluminescence Analysis System \\ Using a Microfluidic Device Capable of Autonomous Liquid Transfer and an Organic Photodiode Detector
}

\author{
Kuizhi $\mathrm{Qu}^{1}$, Kazuhiro MoriokA ${ }^{2}$, Nao Azuma ${ }^{1}$, Moeko Osashima ${ }^{1}$, Akihide Hemmi $^{3}$, \\ Atsushi Shoji ${ }^{2}$, Hiroya Murakami ${ }^{4}$, Norio Teshima ${ }^{4}$, Tomonari Umemura ${ }^{5}$, \\ Shungo Kato ${ }^{1}$, Nahoko Kasai ${ }^{1}$, Katsumi UchiYama ${ }^{1}$ and Hizuru NaKajIma ${ }^{* 1}$ \\ * E-mail : nakajima-hizuru@tmu.ac.jp
}

${ }^{1}$ Department of Applied Chemistry for Environment, Graduate School of Urban Environmental Sciences, Tokyo Metropolitan University, 1-1, Minamiohsawa, Hachioji-shi, Tokyo 192-0397

${ }^{2}$ School of Pharmacy, Tokyo University of Pharmacy and Life Sciences, 1432-1, Horinouchi, Hachioji-shi, Tokyo 192-0392

${ }^{3}$ Mebius Advanced Technology Ltd., 3-31-6-105, Nishiogikita, Suginami-ku, Tokyo 167-0042

${ }^{4}$ Department of Applied Chemistry, Aichi Institute of Technology, 1247, Yachigusa, Yakusa-cho, Toyota-shi, Aichi 470-0392

${ }^{5}$ School of Life Sciences, Tokyo University of Pharmacy and Life Sciences, 1432-1, Horinouchi, Hachioji-shi, Tokyo 192-0392

(Received November 4, 2019; Accepted November 12, 2019)

A novel chemiluminescence analysis system using a polydimethylsiloxane (PDMS) microfluidic device and an organic photodiode (OPD) detector was developed. The sample and reagent solutions in the reservoir on the degassed PDMS microfluidic device were autonomously flowed into the microchannel in the PDMS microfluidic device, since the degassed PDMS resin absorbs the air in the microchannel. The OPD was fabricated by a spincoating method using poly(3-hexylthiophene-2,5-diyl) and [6,6]-phenyl-C61 butyric acid methyl ester as a material of photoelectric conversion layer. The measurement of hydrogen peroxide was evaluated using the chemiluminescence analysis system. SuperSignal ${ }^{\mathrm{TM}}$ ELISA Femto Substrate and Horseradish Peroxidase were used in the measurement. The calibration curve for hydrogen peroxide was linear for concentrations under $3.2 \mathrm{mM}$ with a correlation coefficient of 0.9986 . The limit of detection, defined as three-times the standard deviation of the blank signal, was estimated to be $4.4 \mu \mathrm{M}$. Compared to the hydrogen peroxide assay kit using a 96-well microtiter plate and a micro plate reader, the amount of sample and reagent consumption and the analysis time could be reduced to $1 / 5$ and $1 / 10$, respectively. The chemiluminescence analysis system was successfully used in the determination of hydrogen peroxide in a commercially available disinfectant, oxydol. The chemiluminescence analysis system would be useful for on-site environmental measurement, quality control of food, pointof-care testing etc. since a pump is unnecessary and the detector is very small and lightweight.

Keywords: $\mu$ TAS; microfluidic device; organic photodiode; chemiluminescence analysis; on-site analysis. 